\title{
Anticitrullinated peptide antibodies (ACPA) in the serum of heavy smokers without arthritis - a differential role of associated pulmonary disease?
} \author{
I Haro ${ }^{2}$, R Sanmartí ${ }^{1}$ \\ From 5th European Workshop on Immune-Mediated Inflammatory Diseases \\ Sitges-Barcelona, Spain. 1-3 December 2010
}

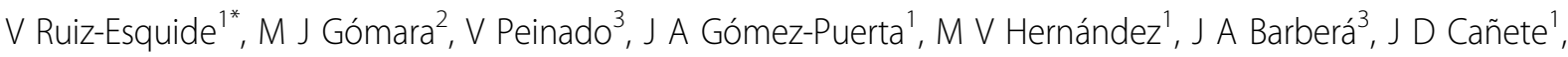

\section{Background}

An increased risk of RA has been described in smokers, but only in ACPA-positive RA patients. The frequency of ACPA in serum of heavy smokers is not known.

\section{Objectives}

Analyze the serum frequency and levels of ACPA on heavy smoker subjects, with and without chronic obstructive pulmonary disease (COPD), and compare them with a healthy control group.

\section{Methods}

Serum samples of 110 heavy smokers (39\% women, $56.9 \pm 10$ years) were obtained.

Subjects were selected from a Pneumology Service database and from hospital workers. They were compared with 209 healthy controls who had never smoked ( $51 \%$ women, $41.8 \pm 12$ years). Both groups were tested for two different antibodies against citrullinated proteins, a commercial anti-CCP2 test and a home-made chimeric fibrin/filaggrin citrullinated synthetic peptide (anti-CFFCP).

Their frequency and levels were compared between groups.

\section{Results}

Of the 110 heavy smokers, 54 had COPD and 56 were healthy smokers. None had RA. Mean packs-year were $44.3 \pm 36(53 \pm 28$ in COPD disease and $36 \pm 16$ in healthy smokers, $\mathrm{p}<0.01)$.

Percentage of positive results and mean serum levels of ACPA in all the study groups are shown in Table 1.

The prevalence of positive anti-CFFCP was higher in the heavy smoker group than in non-smokers, although the difference was not significant. The highest prevalence of positive anti-CFFCP was seen in patients with COPD (7.4\%); the difference was at the limit of statistical significance compared with the control group (2.4\%) (OR:3.26 95\% CI:0.85-12.6 p=0.07). Heavy smokers with COPD had significantly higher

Table 1 Frequency of positive autoantibodies and mean serum levels of antibodies in the study groups

\begin{tabular}{lllll}
\hline & \multicolumn{3}{c}{ HEAVY SMOKERS } & NON SMOKERS \\
\cline { 2 - 5 } & A TOTAL $\mathbf{n = 1 1 0}$ & B COPD $\mathbf{n = 5 4}$ & C NON COPD $\mathbf{n = 5 6}$ & D $\mathbf{n = 2 0 9}$ \\
\hline CFFCP+ (\%) & $5(4.5 \%)$ & $4(7.4 \%)^{*}$ & $1(1.7 \%)$ & $5(2.4 \%)^{*}$ \\
CFFCP mean \pm SD & $0.12 \pm 0.06$ & $0.15 \pm 0.7^{\dagger} \boldsymbol{n}$ & $0.09 \pm 0.5^{\dagger}$ & $0.10 \pm 0.12^{\boldsymbol{q}}$ \\
CCP2+ (\%) & $2(1.8 \%)$ & $2(3.7 \%)$ & $0(0 \%)$ & $4(1.9 \%)$ \\
CCP2 mean \pm SD & $15.62 \pm 4.25$ & $16.2 \pm 5.97^{\ddagger}$ & $15.05 \pm 0.9^{\ddagger}$ & $16.9 \pm 2.78$ \\
\hline
\end{tabular}

${ }^{*} B$ vs $D p=0.07,{ }^{\circ} B$ vs $C p<0.001,{ }^{\circ} B$ vs $D p=0.02,{ }^{\ddagger} B$ vs $C p=0.17$.

'Rheumatology, IQAC-CSIC, Barcelona, Spain

Full list of author information is available at the end of the article 
levels of both autoantibodies than non-smokers and smokers without COPD.

\section{Conclusion}

The prevalence of ACPA in heavy smokers without RA is low, but seems to be higher in heavy smokers with COPD. Larger studies are necessary to confirm these findings and determine the relationship between ACPA and lung disease.

\section{Author details}

${ }^{1}$ Rheumatology, IQAC-CSIC, Barcelona, Spain. ${ }^{2}$ Synthesis and Biomedical Applications of Peptides Unit, IQAC-CSIC, Barcelona, Spain. ${ }^{3}$ Pneumology, Hospital Clinic Barcelona, IQAC-CSIC, Barcelona, Spain.

Published: 25 November 2010

doi:10.1186/1479-5876-8-S1-P55

Cite this article as: Ruiz-Esquide et al:: Anticitrullinated peptide antibodies (ACPA) in the serum of heavy smokers without arthritis - a

differential role of associated pulmonary disease? Journal of Translational Medicine 2010 8(Suppl 1):P55.

Submit your next manuscript to BioMed Central and take full advantage of:

- Convenient online submission

- Thorough peer review

- No space constraints or color figure charges

- Immediate publication on acceptance

- Inclusion in PubMed, CAS, Scopus and Google Scholar

- Research which is freely available for redistribution

Submit your manuscript at www.biomedcentral.com/submit 